\title{
Macroeconomics Determinants of Sovereign Credit Ratings
}

\author{
Soh Wei Chee ${ }^{1}$, Cheng Fan Fah ${ }^{1} \&$ Annuar Md. Nassir ${ }^{1}$ \\ ${ }^{1}$ Faculty of Economics and Management, University Putra Malaysia, Malaysia \\ Correspondence: Soh Wei Chee, Faculty of Economics and Management, University Putra Malaysia, Malaysia. \\ Tel: 601-8660-5841. E-mail: swc.soh@gmail.com
}

Received: November 15, 2014

Accepted: December 12, 2014

Online Published: January 25, 2015

doi:10.5539/ibr.v8n2p42

URL: http://dx.doi.org/10.5539/ibr.v8n2p42

\begin{abstract}
The objective of this paper is to identify the determinants of sovereign credit rating. This study including 53 countries in the study covers from year 2000 to 2011. This study examines nine macroeconomic variables and extended by using three qualitative variables, i.e., history of default, economic development and economic freedom. The results are consistent with previous studies that some macroeconomics variables are determinants of rating. Furthermore, the economic freedom variable serves as a vital factor in determining sovereign credit rating that has been overlooked by the previous studies. This study has added new findings and indicates that the economic freedom of country is decisive factor in assessment.
\end{abstract}

Keywords: sovereign credit rating, macroeconomic, economic freedom variable

\section{Introduction}

The worldwide financial market volatility was triggered by the cycle of global financial crisis throughout these timeline: Asian Financial Crisis (1997-1998), Russia Debt Default (1998), Brazilian Crisis (1998-1999 and 2002), Turkey Crisis (2000-2001), Argentina Crisis (2001), US Subprime Mortgage Crisis (2007-2008), and the recent European Sovereign-Debt Crisis (2008-2013). The history of past financial crises and discussions on volatility of financial markets reminded the public that no assets, including sovereign debt which theoretically is 'credit risk free', can be truly defined as 'risk free'.

Sovereign credit crises can have negative impact on the global economic growth as they affect the global financial market. The falling sovereign debt of the PIIGS (Portugal, Italy, Ireland, Greece and Spain), for instance, encumbered the economic growth of Euro zone as well as the global financial market - in response to the Euro Central Bank and International Monetary Fund (IMF) bailout to secure the Euro monetary system.

As the much needed capital is removed, the country's currency system collapses, resulting in the local currency to depreciate sharply against the U.S. dollar. Inflation rate will increase, and this puts further constraint on the public as an increase in the inflation rate means a rise in the cost of living and unemployment rate. Although the government may recourse to IMF loan, a series of austerity measures have to be implemented to repay the creditor in full.

In conjunction of these impacts, credit rating agencies (CRAs) have become the focus of research in the past two decades, especially the three major CRAs covered by the Standard \& Poor's (S\&P), Moody's and Fitch. Credit ratings agencies (CRAs) were set up in the early 1900s. In conjunction with this, the expansion of capital market and the importance of individual analytic information providers like credit rating agencies brought about the establishment of the National Recognized Statistical Organization (NBSROs) in 1970.

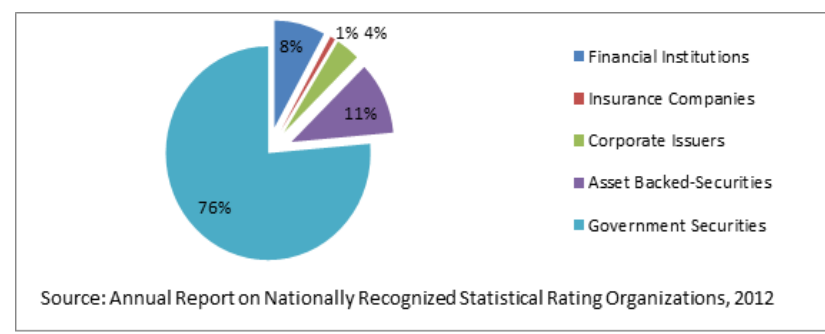

Figure 1. Total ratings of NBSROs under five categories of securities 
Figure 1 shows the total rating of NBSROs by Five Categories of Securities as at Dec 2011. Base on the figure, $76 \%$ of NBSROs' total assessment has been made on government securities rating, which is, the majority of the total rating assessment.

\section{Review of Studies}

A government should control its level of risk aversion by foregoing a higher borrowing cost in order to reduce the inconsistency of its finance costs. There are literatures on the level of risk aversion and on how the government should behave. According to Tobin (1963), the government should ignore the possible risks and solely target debt management in finance cost minimisation and macroeconomic stabilisation. However, Wheeler (1997) stated that the government should act according to the risk preference of the middle voter who is more risk aversion. Cassard and Folkerts-Landau (1997) offered a more rational point of view which stated that the government should determine its risk tolerance level on top of the maximum interest rate cost and the unexpected fluctuation that debt portfolio can be bolstered without imperil the government's intertemporal budget constraints and medium term goals.

De Haan and Amtenbrink (2011) stated that the Credit Rating Agencies (CRAs) supplied two services: the information service and the monitoring service. There are three characteristics which made CRAs highly demanded as emerging markets as compared to developed countries: a significant lack of economic political stability, a lack of market regulation and transparency, and a high degree of volatility and uncertainty (Al-Sakka \& Gwilym, 2010).

The determinants of sovereign rating were firstly investigated by Cantor and Packer (1996) with the following eight factors to consider in resolving a country's credit rating: income per capita, growth of GDP, inflation, fiscal balance, external debt balance, external debt, and the indicators for both economic growth level and default history. They studied the determinants of sovereign credit rating of the Standard \& Poor's and the Moody's, including 49 mature and emerging countries as at 29 September 1995. The study was done using OLS method. They found that the two big players in CRAs (Standard \& Poor's and the Moody's) have similar weightage of variables in sovereign credit rating evaluation.

Bissoondoyal-Bheenick (2005) extended the study in this field by expanding the time period and number of countries involved, and included four different ratings: (1) the local currency ratings, (2) foreign currency ratings, (3) bonds and notes ratings, and (4) bank deposit ratings. The data covered were from December 1995 December 1999 and employed the ordered response model. As the conclusion, the GNP per capita and inflation are the key economic indicators emphasized by the CRAs in determining the ratings.

Bissoondoyal-Bheenick et al. (2006) compared the results of two methods: the Case-based reasoning (CBR) and the ordered probit approach. As expected, the variable of GDP is significant across the rating of the three CRAs: the Standard \& Poor's, the Moody's and the Fitch. The GDP, inflation and real interest rates are significant in determining the sovereign credit rating. The results of the two methods were similar although different methods were used which shows that there is robustness in the result. The variable of mobile phone is significant; this indicates that an advancement level of technology is vital in explaining the fundamental economic of a country.

\section{Research Methodology}

\subsection{Theoretical Framework}

The main role of Credit Rating Agencies (CRAs) is to measure and quantify countries' international borrowing, or sovereign debts creditworthiness in rating form. In main stream, the CRAs focused on the politic, economic and social aspects.

In the aspect of politic, the politic business cycle theory draws the relationship between the politic aspect and the inflation. In this theory, the inflation is a measurement of incumbent government's self-restrain in not being opportunist for election benefits. Voters' dissatisfaction due to high inflation rate may increase the possibilities of political instability.

The aspect of economic is one of the criteria that concerned in sovereign creditworthiness assessment, and related by macroeconomic variables that quantifiable. The sovereign creditworthiness is all about measuring the capacity of a country in servicing external debts. The government's sovereign debt management pattern is indeed the most crucial factor in determining the capacity of external debts servicing. Without a well-planned and efficient debt management, countries may face higher risk in sovereign debt default. Though a country's capacity in repaying external debts is unable to be quantified; however, the sovereign creditworthiness can be measure by observing government's sovereign debt management behavior, which could be traced by the monetary policy and fiscal policy. 
The sovereign debt management and monetary policy are closely related under the linkage of open market operation. In open-market sell, the central bank will sell the government securities to the creditor countries and borrowing capital in foreign currency. The sovereign debt management interrupts in the fiscal policy to help in the minimization of risks, to avoid unanticipated adjustment in taxes and to ensure that the government does not experience fiscal shock. Also, debt overhang theory leads to the measurement of sovereign creditworthiness by using external debt volume over borrowing government's repaying debt capacity. The monetary policy, fiscal policy and the debt overhang theory examine the borrowing government's debt management behavior.

\subsection{Theoretical Model}

The CRAs evaluate sovereign credit rating based on s country's international creditworthiness. The empirical model of international creditworthiness was summarized by Feder and Uy (1985) who studied the variables that affect international creditworthiness and identified their weight. The reduced-form equation is as following:

$$
C W=f(X)
$$

$\mathrm{CW}$ is a measure of international creditworthiness and $\mathrm{X}$ consists of a set of indicators associated to debt repaying capacity of debtor countries.

Unlike previous researchers who tried to measure country's international creditworthiness on their own, Cantor and Packer (1996) takes the CRAs' sovereign credit rating as the international creditworthiness. They were first in identified the determinants of sovereign credit rating of Moody's and Standard and Poor's by using the reduced-form equation. In this study, we employ Ordinary Least Square (OLS) method to identify the determinants of sovereign credit rating.

The ordinary least squares (OLS) estimation achieve best linear unbiased estimator (BLUE) when there are no multicollinearity, when errors are homoscedastic and error terms are serially uncorrelated. The ordinary least squares (OLS) can be derived as a maximum likelihood estimator under the assumption that the errors are normally distributed, i.e. there is no autocorrelation between the errors terms and that they behave homoscedastically. This model uses the grouped data where the average data of each variable are organized according to the time period.

To compare the impact of economic freedom indicator in explaining the sovereign credit rating, there are two equations of ordinary least squares analysis presented as the following:

$$
\begin{gathered}
\sum_{j=1}^{N} S R=\beta_{0}+\sum_{j=1}^{N} \beta_{1}\left(\Delta \frac{\text { debt }}{\text { export }}\right)+\sum_{j=1}^{N} \beta_{2}\left(\Delta \frac{\text { debt }}{G D P}\right)+\sum_{j=1}^{N} \beta_{3}\left(\Delta \frac{\text { foreign reserve }}{G D P}\right)+\sum_{j=1}^{N} \beta_{4}\left(\Delta \frac{M 2}{G D P}\right)+ \\
\sum_{j=1}^{N} \beta_{7}\left(\Delta \frac{\text { export }}{G D P}\right)+\sum_{j=1}^{N} \beta_{5}(\Delta G D P \text { deflator })+\sum_{j=1}^{N} \beta_{6}(\Delta \text { real echg rate })+ \\
\sum_{j=1}^{N} \beta_{8}(\Delta G D P \text { per capita })+\sum_{j=1}^{N} \beta_{9}(\Delta \text { real interest rate })+\sum_{j=1}^{N} \beta_{10}(\text { default history })+ \\
\sum_{j=1}^{N} \beta_{11}(\text { economic development })+\varepsilon_{i} \\
\sum_{j=1}^{N} S R=\beta_{0}+\sum_{j=1}^{N} \beta_{1}\left(\Delta \frac{\text { debt }}{\text { export }}\right)+\sum_{j=1}^{N} \beta_{2}\left(\Delta \frac{\text { debt }}{G D P}\right)+\sum_{j=1}^{N} \beta_{3}\left(\Delta \frac{\text { foreign reserve }}{G D P}\right)+\sum_{j=1}^{N} \beta_{4}\left(\Delta \frac{M 2}{G D P}\right)+ \\
\sum_{j=1}^{N} \beta_{7}\left(\Delta \frac{\text { export }}{G D P}\right)+\sum_{j=1}^{N} \beta_{5}(\Delta G D P \text { deflator })+\sum_{j=1}^{N} \beta_{6}(\Delta \text { real echg rate })+ \\
\sum_{j=1}^{N} \beta_{8}(\Delta G D P \text { per capita })+\sum_{j=1}^{N} \beta_{9}(\Delta \text { real interest rate })+\sum_{j=1}^{N} \beta_{10}(\text { economic freedom })+ \\
\sum_{j=1}^{N} \beta_{11}(\text { economic development })+\sum_{j=1}^{N} \beta_{10}(\text { default history })+\varepsilon_{i}
\end{gathered}
$$

Where SR $=$ Standard \& Poor's sovereign rating grade.

\subsection{Data Description}

In the study, 53 countries were included in the sample size. The sample period covers from January 2000 to December 2011 and the data are occurred in quarterly.

The time series dataset of sovereign credit rating change events are acquired from the Standard \& Poor's (S\&P) website. The sovereign credit rating of foreign currency denominated sovereign bonds are collected over a long period of time. This study focused on Standard \& Poor's (S\&P) instead of Moody's and Fitch which also performs as the major player in Credit Rating Agencies (CRAs) because of the following reasons.

First, Standard \& Poor's (S\&P) behaves more actively in executing sovereign credit rating change announcements; hence, provides more information in the dataset. Evidence can be seen in figure 2 that shows the total ratings of NBSROs at Dec 2011 under the category of government securities - 47\% is occupied by Standard \& Poor's (S\&P) and $41 \%$ by Moody's. 


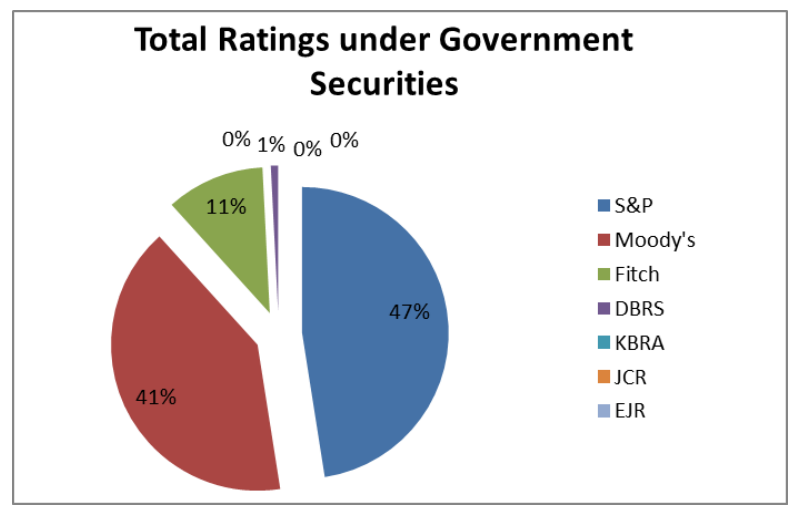

Figure 2. The total ratings of NBSROs under government securities as at Dec 2011

Source: Annual Report on Nationally Recognized Statistical Rating Organizations, 2012.

Second, instead of being the big player among Moody's and Fitch, Standard \& Poor's (S\&P) in most cases performs as the early mover in sovereign credit rating change announcements and provides an accurate assessment overall (Reisen \& Von Maltzan,1999; Norden \& Weber, 2004; Gande \& Parsley, 2005). Third, as study by Hill et.al (2010) shows that sovereign credit rating events made by Standard \& Poor's (S\&P) included more information than those by Moody's and Fitch. Fourth, Standard \& Poor's (S\&P) indeed attained interdependent behaviour in sovereign credit rating assessments and even led in downgraded events of Fitch and upgraded events of Moody's (Brooks et al, 2004).

The rating of each country is grade as follow in Table 1.

Table 1. Ranking grade assigned to standard \& poor's sovereign rating

\begin{tabular}{|c|c|c|c|}
\hline \multicolumn{2}{|c|}{ Description } & \multirow{2}{*}{$\begin{array}{l}\text { Standard \& Poor's Sovereign Ratings } \\
\text { AAA }\end{array}$} & \multirow{2}{*}{$\frac{\text { Ranking Grade }}{21}$} \\
\hline Investment Grade & Minimal credit risk & & \\
\hline & Very low credit risk & $\mathrm{AA}+$ & 20 \\
\hline & & AA & 19 \\
\hline & & AA- & 18 \\
\hline & Low credit risk & $\mathrm{A}+$ & 17 \\
\hline & & A & 16 \\
\hline & & A- & 15 \\
\hline & Moderate credit risk & $\mathrm{BBB}+$ & 14 \\
\hline & & BBB & 13 \\
\hline & & BBB- & 12 \\
\hline \multirow[t]{11}{*}{ Speculative Grade } & Substantial credit risk & $\mathrm{BB}+$ & 11 \\
\hline & & BB & 10 \\
\hline & & BB- & 9 \\
\hline & High credit risk & $\mathrm{B}+$ & 8 \\
\hline & & B & 7 \\
\hline & & B- & 6 \\
\hline & Very high credit risk & $\mathrm{CCC}+$ & 5 \\
\hline & & $\mathrm{CCC}$ & 4 \\
\hline & & CCC- & 3 \\
\hline & Near default & $\mathrm{CC}$ & 2 \\
\hline & Default & $\mathrm{SD} / \mathrm{D}$ & 1 \\
\hline
\end{tabular}


According to $\mathrm{Hu}$ et al. (2002), the variables commonly used by previous research can be categorized into four groups: (1) Liquidity variables, (2) Solvency variables, (3) Macroeconomic fundamentals and (4) External shocks. The study included 9 macroeconomics variables in the study: ratio of external debt over export, external debt over GDP, foreign reserve over GDP, money supply over GDP, export over GDP; growth rate of GDP deflator, real exchange rate, GDP per capita, real interest rate. This study also including the three quantitative variables: economic freedom of the world, economic development indicator and default history. The variable in measuring the economic freedom of one country has been added into the research. The variable of Economic Freedom of the World (EFW) occurred through Faser Institute was introduced by Gwartney and Lawson (2000), where Cumming (2000) and Gwartney and Lawson (2003) conclude that the methodologies used by Fraser Institute were more precise and transparent.

\section{Results}

The analysis presentation flows with the correlation result between the exogenous variables, regression results and variance inflation factor (VIF) result. The two multiple regression results of will be present as equation 1 (consists of 11 exogenous variables excluding economic freedom), and equation 2 (consists of 12 exogenous variables including economic freedom), followed by the discussion of the results.

Table 2. Correlation matrix

\begin{tabular}{|c|c|c|c|c|c|c|c|c|c|c|c|c|}
\hline & $\begin{array}{l}\text { Interest } \\
\text { rate }\end{array}$ & GDPD & GDPC & $\begin{array}{c}\text { Foreign } \\
\text { Exchange/GDP }\end{array}$ & Export/GDP & $\mathrm{M} 2 / \mathrm{GDP}$ & $\begin{array}{c}\text { Exchange } \\
\text { rate }\end{array}$ & $\begin{array}{l}\text { Economic } \\
\text { development }\end{array}$ & $\begin{array}{l}\text { Default } \\
\text { history }\end{array}$ & $\begin{array}{c}\text { Economic } \\
\text { freedom } \\
\text { indicator }\end{array}$ & $\begin{array}{l}\text { External } \\
\text { debt/GDP }\end{array}$ & $\begin{array}{c}\text { External } \\
\text { debt/export }\end{array}$ \\
\hline Interest rate & 1.000 & & & & & & & & & & & \\
\hline GDPD & 0.072 & 1.000 & & & & & & & & & & \\
\hline GDPC & -0.238 & -0.244 & 1.000 & & & & & & & & & \\
\hline $\begin{array}{l}\text { Foreign } \\
\text { Exchange/GDP }\end{array}$ & -0.120 & -0.086 & 0.017 & 1.000 & & & & & & & & \\
\hline Export/GDP & -0.086 & -0.261 & 0.129 & 0.058 & 1.000 & & & & & & & \\
\hline $\mathrm{M} 2 / \mathrm{GDP}$ & -0.206 & -0.137 & 0.199 & -0.054 & 0.092 & 1.000 & & & & & & \\
\hline Exchange rate & 0.142 & 0.049 & -0.060 & -0.078 & -0.017 & 0.197 & 1.000 & & & & & \\
\hline $\begin{array}{l}\text { Economic } \\
\text { development }\end{array}$ & -0.365 & 0.348 & 0.598 & 0.249 & -0.178 & -0.246 & -0.230 & 1.000 & & & & \\
\hline Default history & 0.082 & -0.056 & -0.120 & -0.030 & -0.133 & -0.049 & 0.106 & -0.127 & 1.000 & & & \\
\hline $\begin{array}{l}\text { Economic freedom } \\
\text { indicator }\end{array}$ & -0.448 & -0.053 & 0.583 & 0.020 & 0.258 & -0.387 & -0.153 & 0.595 & -0.202 & 1.000 & & \\
\hline External debt/GDP & 0.046 & 0.077 & -0.006 & 0.597 & -0.046 & -0.059 & -0.105 & 0.224 & 0.050 & -0.002 & 1.000 & \\
\hline $\begin{array}{l}\text { External } \\
\text { debt/export }\end{array}$ & 0.049 & 0.073 & -0.117 & -0.035 & -0.283 & -0.104 & -0.129 & 0.063 & 0.678 & -0.077 & 0.176 & 1.000 \\
\hline
\end{tabular}

From the correlation matrix result, the short term liquidity of one country (represented by the ratio of external debt over GDP) has a strong uphill linear relationship with the default history. Debt sustainability is measured with the indicator of debts with respect to the repayment capability of one country. Repayment capability is typically linked with the government revenues, GDP and exports. When a country has high ratio of external debt over export, the country is experiencing a short term liquidity problem. The strong uphill relationship between the short term liquidity and default history show that a country with a short term liquidity problem has a higher possibility to default.

The economic development has a moderate positive relationship with the GDP per capita. This simply shows that the advanced countries have a higher tendency to have higher GDP per capita. The indicator economic freedom of the world introduced by Gwartney and Lawson (2000) refers to the indicator measuring the freedom of individuals to claim ownership of their asset legally and to use, exchange or give their asset to any parties legally. This indicator is positively correlated with GDP per capita and the economic development indicator which shows that advanced countries with high GDP per capita will tend to have higher scores in indicator economic freedom of the world. 
Table 3. Multiple regression result with sample period 2000-2011

\begin{tabular}{|c|c|c|}
\hline Explanatory variables & Equation 1 & Equation 2 \\
\hline \multirow[t]{2}{*}{ Default history } & -8.482614 & -7.780677 \\
\hline & $\left(0.000^{* * *}\right)$ & $\left(0.000^{* * *}\right)$ \\
\hline \multirow[t]{2}{*}{ Economic development indicator } & 12.41518 & 8.029859 \\
\hline & $\left(0.000^{* * *}\right)$ & $\left(0.000^{* * *}\right)$ \\
\hline \multirow[t]{2}{*}{ Economic freedom of the world } & & 11.88165 \\
\hline & & $(0.000 * * *)$ \\
\hline \multirow[t]{2}{*}{ Growth of real exchange rate } & -3.416787 & -4.997838 \\
\hline & $\left(0.0007^{* * *}\right)$ & $\left(0.000^{* * *}\right)$ \\
\hline \multirow[t]{2}{*}{ Growth rate of GDP deflator } & -2.885984 & -1.559877 \\
\hline & $(0.004 * * *)$ & $(0.1192)$ \\
\hline \multirow[t]{2}{*}{ Growth rate of GDP per capita } & 0.969732 & 2.009334 \\
\hline & $(0.3325)$ & $(0.0449 * *)$ \\
\hline \multirow[t]{2}{*}{ Growth rate of real interest rate } & -0.913735 & -3.744338 \\
\hline & $(0.3611)$ & $\left(0.0002^{* * *}\right)$ \\
\hline \multirow[t]{2}{*}{ Ratio of export over GDP } & 7.391281 & 1.835239 \\
\hline & $\left(0.000^{* * *}\right)$ & $(0.0669 *)$ \\
\hline \multirow[t]{2}{*}{ Ratio of external debt over export } & -0.913735 & -1.684264 \\
\hline & $(0.3611)$ & $(0.0925 *)$ \\
\hline \multirow[t]{2}{*}{ Ratio of external debt over GDP } & -2.537184 & -2.29179 \\
\hline & $(0.0114 * *)$ & $(0.0222 * *)$ \\
\hline \multirow[t]{2}{*}{ Ratio of foreign reserve over GDP } & 1.867783 & 3.65187 \\
\hline & $(0.0622 *)$ & $\left(0.0003^{* * *}\right)$ \\
\hline \multirow[t]{2}{*}{ Ratio of money supply over GDP } & 6.687346 & 8.377418 \\
\hline & $(0.000 * * *)$ & $(0.000 * * *)$ \\
\hline Adjusted R-square & 0.763867 & 0.821359 \\
\hline Durbin Watson & 1.490796 & 1.71538 \\
\hline
\end{tabular}

Note. Number in each bracket is t-statistic and p-value, significant at $(*) 0.05$ level, $(* *) 0.01$ level, $(* * *) 0.001$ level.

The multiple regression results above are free from econometric problems; both grouped data have no autocorrelation, multicollinearity problem and behaved homoscedasticity.

From the multiple regression result of equation 1 that consists of eleven exogenous variables excluding default history, eight exogenous variables significantly determine the sovereign credit rating. There are four determinants that are found to be positively related to the rating and four determinants negatively related to the rating. The economic development indicator, ratio of export over GDP and money supply over GDP are positively significant to determine sovereign credit rating at $1 \%$ significant level. The ratio of foreign reserve over GDP is positive significant determinant at $10 \%$ level. Therefore, advanced (developing) country with a high (low) ratio of export, high (low) money supply and high (low) scores in economic freedom of the world will tend to have a higher (lower) grade in sovereign credit rating, where grade 21 refers to the highest rating of AAA.

There are four exogenous variables that are negatively related in determining the sovereign credit rating: the default history, growth rate of real exchange rate and GDP deflator are significant at $1 \%$ level; while ratio of external debt over GDP is significant at 5\% level. Hence, local currency appreciation (depreciation) with default history, (high) inflation and free from short term liquidity problem (defined by the ratio of external debt over export) have a higher tendency to score higher sovereign credit rating.

There is a question, how high (low) is the exogenous variables supposed to be to make this happen? This can be explained by the method mentioned in Chapter Three; i.e., to scale up the data. To scale up the data, the exogenous variables data are presented by the ratio over the benchmark countries. The benchmark countries refer to the risk-free countries that maintain highest sovereign credit rating (i.e. AAA grade 21) and do not experience rating change throughout the study period. Hence, the definition of the term "high" ("low") in exogenous variables in the discussion refers to the high (low) ratio of that exogenous variable over the benchmark countries. 
Equation 2 includes economic freedom in the analysis in order to make the comparison. The results in Equation 2 show that there are 11 variables that significantly determine sovereign credit rating, except for inflation. By including the variable of economic freedom, the results show that the ratio of export over GDP, foreign reserve over GDP and external debt over GDP are significant in determining the sovereign credit rating.

Six variables positively determine the sovereign credit rating: the growth rate of GDP per capita, ratio of foreign reserve over GDP, export over GDP, money supply over GDP, economic development indicator and economic freedom of the world. Hence, advanced countries with high (low) scores in economic freedom, high (low) in GDP per capita, foreign reserve, export \& money supply, tend to have higher (lower) sovereign credit ratings.

Five variables have negative relationship with the sovereign credit rating: the default history, the growth rate of real interest rate, real exchange rate, ratio of external debt over GDP and external debt over export. The ratio of external debt over GDP refers to the long term solvency, and the ratio of external debt over export refers to the short term liquidity. Hence, a country with (without) default history, experiences long term and short term liquidity problem in repaying the debts with high (low) interest rate and depreciate (appreciate) local currency contributes to lower (higher) sovereign credit rating.

The two equations produce similar result, but the R-square statistic of equation 2 (82.14\%) is higher than equation 1 (76.39\%). This shows that the economic freedom plays an important role as a determinant in explaining sovereign credit rating. Thus, including economic freedom as one of the exogenous variables improves the fitness of equation in explaining sovereign credit ratings.

In both of the OLS results, the qualitative indicator of economic freedom and the development are significant in determining the sovereign credit rating. This indicates that Standard \& Poor's takes qualitative measurement into account, especially the economic freedom of the countries. Also, the short term liquidity of a country (i.e. ratio of external debt over export) has substantial weight compared to the long term solvency of a country (i.e. ratio of external debt over GDP). This shows that Standard \& Poor's is concerned more on the short term liquidity in shaping the sovereign credit rating of a country. For Standard \& Poor's, export is rather a better measurement of capability to repay the debt, instead of the GDP.

Table 4. Variance Inflation Factor (VIF) result

\begin{tabular}{|c|c|c|c|c|c|c|c|c|c|c|c|c|}
\hline & $\begin{array}{l}\text { Interest } \\
\text { rate }\end{array}$ & GDPD & GDPC & $\begin{array}{c}\text { Foreign } \\
\text { Exchange/GDP }\end{array}$ & $\begin{array}{l}\text { Export/ } \\
\text { GDP }\end{array}$ & $\begin{array}{l}\text { M2/ } \\
\text { GDP }\end{array}$ & $\begin{array}{c}\text { Exchange } \\
\text { rate }\end{array}$ & $\begin{array}{l}\text { Economic } \\
\text { development }\end{array}$ & $\begin{array}{c}\text { Default } \\
\text { development }\end{array}$ & $\begin{array}{l}\text { Economic } \\
\text { freedom } \\
\text { indicator }\end{array}$ & $\begin{array}{l}\text { External } \\
\text { debt/GDP }\end{array}$ & $\begin{array}{c}\text { External } \\
\text { debt/export }\end{array}$ \\
\hline Interest rate & 1.000 & & & & & & & & & & & \\
\hline GDPD & 1.005 & 1.000 & & & & & & & & & & \\
\hline GDPC & 1.060 & 1.063 & 1.000 & & & & & & & & & \\
\hline $\begin{array}{l}\text { Foreign Exchange/ } \\
\text { GDP }\end{array}$ & 1.014 & 1.007 & 1.000 & 1.000 & & & & & & & & \\
\hline Export/GDP & 1.007 & 1.073 & 1.017 & 1.003 & 1.000 & & & & & & & \\
\hline M2/GDP & 1.044 & 1.019 & 1.041 & 1.003 & 1.009 & 1.000 & & & & & & \\
\hline Exchange rate & 1.020 & 1.002 & 1.004 & 1.006 & 1.000 & 1.041 & 1.000 & & & & & \\
\hline $\begin{array}{l}\text { Economic } \\
\text { development }\end{array}$ & 1.153 & 1.138 & 1.557 & 1.066 & 1.032 & 1.064 & 1.055 & 1.000 & & & & \\
\hline $\begin{array}{l}\text { Default } \\
\text { development }\end{array}$ & 1.006 & 1.003 & 1.015 & 1.001 & 1.018 & 1.002 & 1.011 & 1.042 & 1.000 & & & \\
\hline $\begin{array}{l}\text { Economic freedom } \\
\text { indicator }\end{array}$ & 1.251 & 1.003 & 1.514 & 1.000 & 1.071 & 1.175 & 1.024 & 1.548 & 1.042 & 1.000 & & \\
\hline $\begin{array}{l}\text { External } \\
\text { debt/GDP }\end{array}$ & 1.002 & 1.006 & 1.000 & 1.555 & 1.002 & 1.004 & 1.011 & 1.053 & 1.003 & 1.000 & 1.000 & \\
\hline $\begin{array}{l}\text { External } \\
\text { debt/export }\end{array}$ & 1.002 & 1.005 & 1.014 & 1.001 & 1.087 & 1.011 & 1.017 & 1.004 & 1.842 & 1.006 & 1.032 & 1.000 \\
\hline
\end{tabular}


The Variance Inflation Factor (VIF) result shows the range of VIF statistics that lies between 1.55657 and 1 . This shows that there is no severe mulcollinearity problem that occurs between the exogenous variables.

\section{Conclusions}

The sovereign credit crises can hurt the global economic growth through the hit on the globalization financial market. The investors entrust the rating that is analysed by the Credit Rating Agencies (CRAs) as a guideline that reflects a country's creditworthiness. The previous studies also suggested for investors to refer to a reliable indicator that reflects the country's risk for the international asset allocation. Brooks et al. (2004) affirm that investors were getting more interested on sovereign credit rating due to the unavoidable globalization of market.

This study examined the exogenous variables determining the sovereign credit rating 53 countries over the 2000-2011 periods. In the model including economic freedom increased the fitness of the model.

Another distinct finding from this study is the economic freedom indicator significantly determines the country's rating. This shows that the sovereign credit rating assessment focus on both the quantitative and qualitative variables. The two qualitative variables: default history and the economic development indicator that significantly determining sovereign credit rating and consistent with the previous studies; but the indicator of economic freedom is yet to be examine by previous studies.

The previous literature found that the economics freedom indicator is a positive determinant of foreign direct reserve (FDI) inflow and meanwhile the FDI inflow has positive relationship with the economic growth. (De Haan and Sturm, 2000; Sturm and De Haan, 2001; and Azman-Saini et.al, 2003) In the study of Azman-Saini et.al (2010), the findings do not show significant impact of FDI on output growth. However, in line with Azman-Saini et.al (2003), the country's FDI inflow positively affect by the score of economic freedom. The countries have high score in economic freedom positively significant in the presence of multinational corporations (MNCs).

The high score in economic freedom indicates the country have high level of freedom in trading with foreigners and foreign countries. The local firms easily have a R\&D knowledge exchange with the foreign countries entangle with new technology. The increase level of technology in the local firms helps in getting more competitiveness among the international firms in international market. A complete economic structure that easily access to the foreign traders and foreign currency attract more FDI inflow to the country.

This is considering as an important result that suggests that economic freedom of one country do impact on FDI inward and R\&D spillover, as well as the sovereign credit rating that define as the country rating. However, this important issue somehow has been ignored in the previous studies. This findings show that the credit rating agencies (CRA) are both backward-looking and forward looking in determining the sovereign credit rating.

\section{References}

Al-Sakka, R., \& Gwilym, O. (2010). Split sovereign ratings and rating migrations in emerging economies. Emerging Markets Review, 11, 79-97. http://dx.doi.org/10.1016/j.ememar.2009.11.005

Azman-Saini, W. N. W., Baharumshah, A. Z., \& Law, S. H. (2003). Foreign direct investment, economic freedom and growth: New evidence from Latin America. European Journal of Political Economy, 19(3), 529-545. http://dx.doi.org/10.1016/S0176-2680(03)00011-9

Azman-Saini, W. N. W., Baharumshah, A. Z., \& Law, S. H. (2010). Foreign direct investment, economic freedom and economic growth: International evidence. Economic Modelling, 27, 1079-1089. http://dx.doi.org/10.1016/j.econmod.2010.04.001

Bissoondoyal-Bheenick, E. (2005). An analysis of determinants of sovereign ratings. Global Finance Journal, 15, 251-280. http://dx.doi.org/10.1016/j.gfj.2004.03.004

Bissoondoyal-Bheenick, E., Brooks, R., \& Yip Angela, Y. N. (2006). Determinants of sovereign ratings: A comparison of case-based reasoning and ordered probit approaches. Global Finance Journal, 17, 136-154. http://dx.doi.org/10.1016/j.gfj.2006.06.001

Brooks, R., Faff, R., Hillier, D., \& Hillier, J. (2004). The national market impact of sovereign rating changes. Journal of Banking and Finance, 28, 233-250. http://dx.doi.org/10.1016/S0378-4266(02)00406-5

Cantor, R., \& Packer, F. (1996). Determinants and impact of sovereign credit ratings. Federal Reserve Bank of New York Economic Policy Review, 1-15 October.

Cassard, M., \& Folkerts-Landau, D. (1997). Risk management of sovereign assets and liabilities. IMF Working Paper, WP/97/166. 
Cummings, J. T. (2000). Economic freedom indices: Their use as tools for monitoring and evaluation. SCS Working Paper (00/01), 1-64.

De Haan, J., \& Amtenbrink, F. (2011). Credit rating agencies. De Nederlandsche Bank Working Paper, 278.

De Haan, J., \& Sturm, J. E. (2000). On the relationship between economic freedom and economic growth. European Journal of Political Economy, 16, 215-241. http://dx.doi.org/10.1016/S0176-2680(99)00065-8

Fraser Institute. (n. d.). Retrieved from http://www.freetheworld.com/

Gande, A., \& Parsley, D. C. (2005). News spillovers in the sovereign debt market. Journal of Financial Economics, 75, 691-734. http://dx.doi.org/10.1016/j.jfineco.2003.11.003

Gwartney, J., Lawson, R., \& Samida, D. (2000). Economic freedom of the world 2000. Annual Report, Retrieved from http://www.freetheworld.com

Hanke, S. H., \& Walters, S. J. K. (1997). Liberty, Equality, Prosperity. A Report to the Senate Joint Economic Committee, Washington, D.C.: U.S. Senate.

Hill, P., Brooks, R., \& Faff, R. (2010). Variations in sovereign credit quality assessments across rating agencies. Journal of Banking and Finance, 34, 1327-1343. http://dx.doi.org/10.1016/j.jbankfin.2009.11.028

Hu, Y. T., Kiesel, R., \& Perraudin, W. (2002). The estimation of transition matrices for sovereign credit ratings. International Monetary Fund, 69. IMF - World Economic Outlook WEO. Retrieved from http://www.imf.org/external/ns/cs.aspx?id=28

Norden, Lars, Weber, \& Martin. (2004). Informational efficiency of credit default swaps and stock markets: the impact of credit rating announcements. Journal of Banking and Finance, 28, 2813-2843.

O'Driscoll, Jr. G. P., Holmes, K. R., \& Kirkpatrick, M. (2001). 2001 index of economic freedom. Heritage Foundation.

Reisen, Helmut, Von Maltzan, \& Julia. (1999). Boom and bust and sovereign ratings. International Finance, 2(2), 273-279. http://dx.doi.org/10.1111/1468-2362.00028

Standard and Poor's. (2005). Sovereign credit ratings: A primer. Retrieved from http://www.standardandpoors.com/

Sturm, J. E., \& De Haan, J. (2001). Inflation in developing countries: Does central bank independence matter? CESifo Working Paper Series, 511, CESifo Group Munich.

Wheeler, G. (1997). Excellence in debt management: The strategies of leading international borrowers. Sovereign Debt Management in New Zealand, Euromoney Publications.

Zajenkowski, M., Stolarski, M., \& Meisenber, G. (2013). Openness, economic freedom and democracy moderate the relationship between National Intelligence and GDP. Personality and Individual Differences, 55(4), 391-398. http://dx.doi.org/10.1016/j.paid.2013.03.013

\section{Copyrights}

Copyright for this article is retained by the author(s), with first publication rights granted to the journal.

This is an open-access article distributed under the terms and conditions of the Creative Commons Attribution license (http://creativecommons.org/licenses/by/3.0/). 